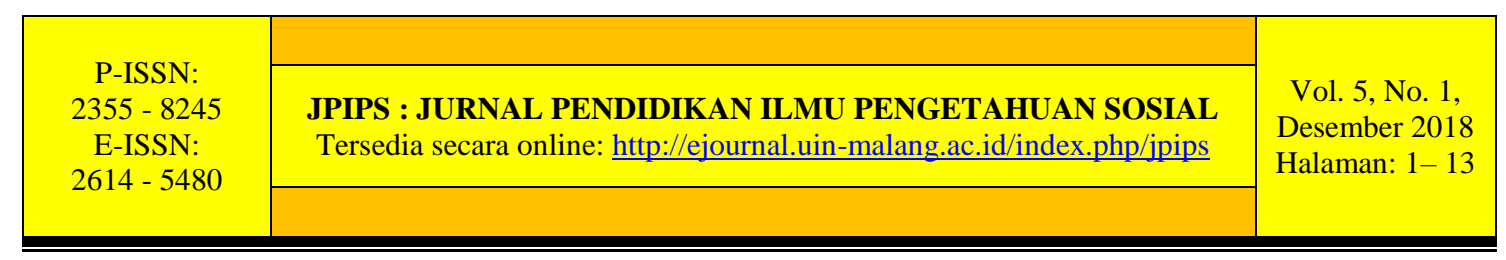

\title{
PERAN PEMERINTAH KOTA MALANG DALAM MENINGKATKAN KESIAPSIAGAAN MASYARAKAT MENGHADAPI BENCANA (STUDI MANAJEMEN BENCANA)
}

\author{
Rusli', Ayu Fitriatul 'Ulya ${ }^{2}$ \\ ${ }^{1}$ UIN Maulana Malik Ibrahim Malang, ${ }^{2} \mathrm{CV}$ Sagamartha \\ ${ }^{1}$ rusli@fis.uin-malang.ac.id, ${ }^{2}$ ayuplanologi@gmail.com
}

\begin{abstract}
Abstrak: Di Indonesia, bahaya-bencana seperti banjir, kekeringan, badai, dan longsor telah menyebabkan banyak kehilangan nyawa manusia dan penghidupan, hancurnya ekonomi dan infrastruktur, perubahan tatanan sosial juga kerusakan lingkungan. Dalam menghadapi bencana, peningkatan kesiapsiagaan sistem dalam masyarakat untuk mengurangi resiko bahaya bencana dilakukan melalui upaya mitigasi dan adaptasi. Berdasarkan undang-undang No. 26 Tahun 2007 tentang penataan ruang menegaskan mitigasi bencana menjadi suatu aspek yang penting diperhatikan. Kota Malang Jawa Timur termasuk wilayah yang tercatat berpotensi rawan terjadinya bencana, baik banjir, longsor, gempa tektonik ataupun gempa vulkanik. Penelitian ini bertujuan untuk mengetahui upaya Pemerintah Kota Malang untuk meningkatkan kesiapsiagaan masyarakat dalam menghadapi ancaman bencana di Kota Malang. Metode yang digunakan adalah pendekatan positivisme dengan pendekatan kualitatif. Hasil penelitian menunjukkan bahwa kesiapsiagaan pemetintah Kota Malang dalam menghadapi bencana yaitu dengan mitigasi struktural dan non struktural. Adapun upaya mitigasi struktural yang dilakukan yaitu perbaikan saluran drainase perkotaan, memperbanyak RTH maupun RTNH, gencar dalam program penghijauan dengan membangun taman kota dimana sebagai tempat wisata juga berguna untuk RTH perkotaan, normalisasi sungai, melakukan penghijauan di bantaran sungai Brantas dan sungai kecil lainnya dan pemotongan pohon besar dijalan. Sedangkan upaya dalam mitigasi non struktural yaitu adanya peraturan daerah yang mengatur kebencanaan (Peraturan Daerah Kota Malang Nomor 1 Tahun 2017 Tentang Penyelenggaraan Penanggulangan Bencana, Rencana Strategis (RENSTRA) BPBD Kota Malang Tahun 2015 - 2018), membangun sinergi program dengan seluruh pelaku (kementerian, lembaga negara, organisasi sosial, lembaga usaha, dan perguruan tinggi) untuk memberdayakan masyarakat, melakukan simulasi peningkatan pengetahuan dan kesadaran masyarakat, peningkatan kapasitas masyarakat untuk mengurangi dan beradaptasi dengan risiko bencana dengan melakukan simulasi maupun pengarahan
\end{abstract}

\section{Kata Kunci: bencana, kesiapsiagaan dan mitigasi}

Abstract: In Indonesia, the dangers of disasters such as floods, droughts, storms, and landslides have caused much loss of human lives and livelihoods, economic and infrastructure degradation, social order changes as well as environmental damage. In the face of disasters, the improvement of the system's preparedness in the community to reduce the risk of hazards is done through mitigation and adaptation efforts. Under Law No.26 of 2007 on spatial planning confirms disaster mitigation to be an important 
aspect of attention. Malang city of East Java including the recorded area is potentially prone to disasters, either flood, landslides, tectonic earthquakes or volcanic earthquakes. This study aims to determine the efforts of Malang City Government to improve community preparedness in facing the threat of disaster in Malang. The method used is positivism approach with qualitative approach. The result of this research indicates that the readiness of Malang City Government in facing disaster is with structural and non-structural mitigation. The structural mitigation effort that is done is the improvement of urban drainage channels, increasing the RTH and RTNH, incessant in the greening program by building a city park where as a tourist place is also useful for urban $R T H$, river normalization, reforestation on the banks of the Brantas river and other small rivers and cutting big trees on the street. While the effort in non-structural mitigation is the existence of regional regulations governing disaster (Malang Regional Regulation No. 1 of 2017 on Disaster Management Implementation, Strategic Plan (RENSTRA) BPBD Malang City 2015 - 2018), build synergy program with all actors (ministries, state institutions, social organizations, business entities, and universities) to empower communities, simulate increased knowledge and community awareness, increase community capacity to reduce and adapt to disaster risks by simulating and direction.

\section{Keywords: disaster, preparedness and mitigation}

\section{PENDAHULUAN}

Kota-kota di Indonesia memiliki beragam karakter geografis sesuai bentang alam negeri ini yang mencakup pegunungan hingga pesisir dan kepulauan. Dalam perkembangannya, setiap kota akan menghadapi isu, masalah, maupun kebutuhan yang berbeda-beda dalam memenuhi tujuan pembangunannya. Dalam mewujudkan ruang yang aman, nyaman, produktif, dan berkelanjutan di seluruh kota di Indonesia diperlukan suatu pendekatan pembangunan yang peka terhadap keragaman karakteristik berbagai kota tersebut.

Di Indonesia, bahaya-bencana seperti banjir, kekeringan, badai, dan longsor telah menyebabkan banyak kehilangan nyawa manusia dan penghidupan, hancurnya ekonomi dan infrastruktur, perubahan tatanan sosial juga kerusakan lingkungan. Frekuensi dan intensitas bahaya-bencana ini cenderung meningkat. Dalam menghadapi bencana, peningkatan ketahanan sistem dalam masyarakat untuk mengurangi resiko bahaya melalui upaya mitigasi dan adaptasi. Hal ini sesuai juga dengan pendapat Entatarina Simanjuntak bahwa upaya pemerintah untuk melakukan upaya pencegahan dan penanggulangan bencana tidak dapat berhasil tanpa partisipasi aktif dari masyarakat, untuk itulah pemerintah berkomitmen untuk meningkatkan pengetahuan dan kemampuan masyarakat dalam upaya adaptasi dan mitigasi bencana terhadap dampak perubahan iklim dan bencana (urban resilience), (Simanjuntak, 2016). Berdasarkan pengertiannya, mitigasi yaitu serangkaian upaya untuk mengurangi resiko bencana, baik melalui pembangunan fisik maupun penyadaran dan peningkatan kemampuan menghadapi bencana. Djauhari Noor mendefinisikan mitigasi bencana sebagai istilah yang digunakan untuk menuju pada tindakan untuk mengurangi dampak dari suatu bencana yang dapat dilakukan sebelum bencana itu terjadi, termasuk kesiapan dan tindakan-tindakan pengurangan resiko jangka panjang (Noor, 2014). Sementara adaptasi merupakan tindakan penyesuaian sistem alam dan sosial untuk menghadapi dampak negatif, baik dari kerawanan bencana maupun perubahan iklim. 
Undang-undang No.26 Tahun 2007 tentang penataan ruang menegaskan mitigasi bencana menjadi suatu aspek yang penting diperhatikan. Bahwa penataan ruang wajib memperhatikan aspek kebencanaan yang berada di dalam suatu daerah dengan mengintegrasikan mitigasi. Menimbang kondisi tersebut, maka sesuai dengan amanat UU 26/2007 tentang Penataan Ruang, maka kegiatan peningkatan kualitas tata ruang berbasis adaptasi atau kesiap siagaan diperlukan dalam upaya miitigasi/pengurangan risiko, agar kemungkinan timbulnya kerusakan atau korban lebih besar di masa mendatang dapat diantisipasi sejak dini.

Dari beberapa wilayah di Indonesia, Kota Malang Jawa Timur termasuk wilayah yang tercatat berpotensi rawan terjadinya bencana, baik gempa tektonik ataupun gempa vulkanik. Hal tersebut karena wilayah kota Malang dekat dengan lautan lepas bagian selatan yaitu Samudera Hindia yang terdapat zona penunjaman lempeng yang berakibat terjadinya gempabumi, kemudian wilayah kota Malang dikelilingi oleh gunung aktif. Wilayah Malang bagian utara dekat dengan gunung Arjuno, bagian timur dekat dengan gunung Semeru, bagian barat dekat dengan gunung Kawi dan Panderman, sebelah selatan dekat dengan gunung Kelud. Selain itu kota Malang juga dilewati oleh sungai Brantas yang mana sebagian tempat misalnya Kota Lama jika terjadi hujan deras air sungai akan meluap ke perkampungan yang dekat dengan bantaran sungai Brantas. Selain itu potensi longsor juga ada di kota Malang misalnya di Bareng yang apabila terajadi hujan deras tanah-tanah banyak yang larut dan jatuh ke rumah penduduk tapi selama ini masih belum terjadi longsor dalam skala besar.

Oleh sebab itu, warga masyarakat khususnya kota Malang harus memiliki kesadaran dalam hal bertingkah laku terhadap lingkungan jangan sampai membuat kerusakan karena akan berdampak tidak hanya pada dirinya sendiri tetapi pada orang lain. Selain itu masyarakat perlu kesiapsiagaan sejak awal dalam menghadapi bencana, mulai mengenal potensi bencana apa saja yang akan terjadi pada daerah mereka tempati, sampai bagaimana cara atau apa yang harus diperbuat pada saat bencana terjadi agar masyarakat selamat baik nyawa maupun harta dan lain sebagianya. Kesiapsiagaan adalah tindakan-tindakan yang memungkinkan pemerintah, organisasi, masyarakat, dan individu untuk mampu menanggapi suatu situasi bencana secara cepat dan tepat guna (Carter (1991) dalam LIPI-UNESCO/ISDR, 2006).

Pemerintah kota Malang harus mempunyai peran penting dalam upaya meningkatkan kesiapsiagaan masyarakat akan bencana. Upaya pemerintah Kota Malang dalam peningkatan kesiapsiagaan masyarakat dalam menghadapi bencana bertujuan untuk mengantisipasi secara tepat apa yang harus dilakukan ketika bencana itu benarbenar akan datang dan dapat meminimalisir jatuhnya korban. Selama ini lebih banyak melakukan kegiatan pasca bencana berupa tanggap darurat dan rehabilitasi daripada kegiatan sebelum bencana berupa kesiapsiagaan dan mitigasi menghadapi bencana. Konsep kesiapsigaan dalam menghadapi bencana telah diterapkan dalam salah satu proses menagemen bencana yang memandang kebencanaan bukan hanya meliputi kegiatan pasca tetapi juga sebelum dan pada saat bencana terjadi. Rahmat mengungkapkan bahwa manajemen bencana merupakan seluruh kegiatan yang meliputi aspek perencanaan dan penanggulangan bencana, pada sebelum, saat dan sesudah terjadi bencana (Purnomo, 2010). Khan secara komprehensif juga menjabarkan tentang definisi managemen bencana, yaitu "Sum Total of all activities, programmers and measures wich can be taken up before, during and after a disaster with the purpose to avoid a disaster, reduce, its impact or recover from its losser" (Khan, 2008). 


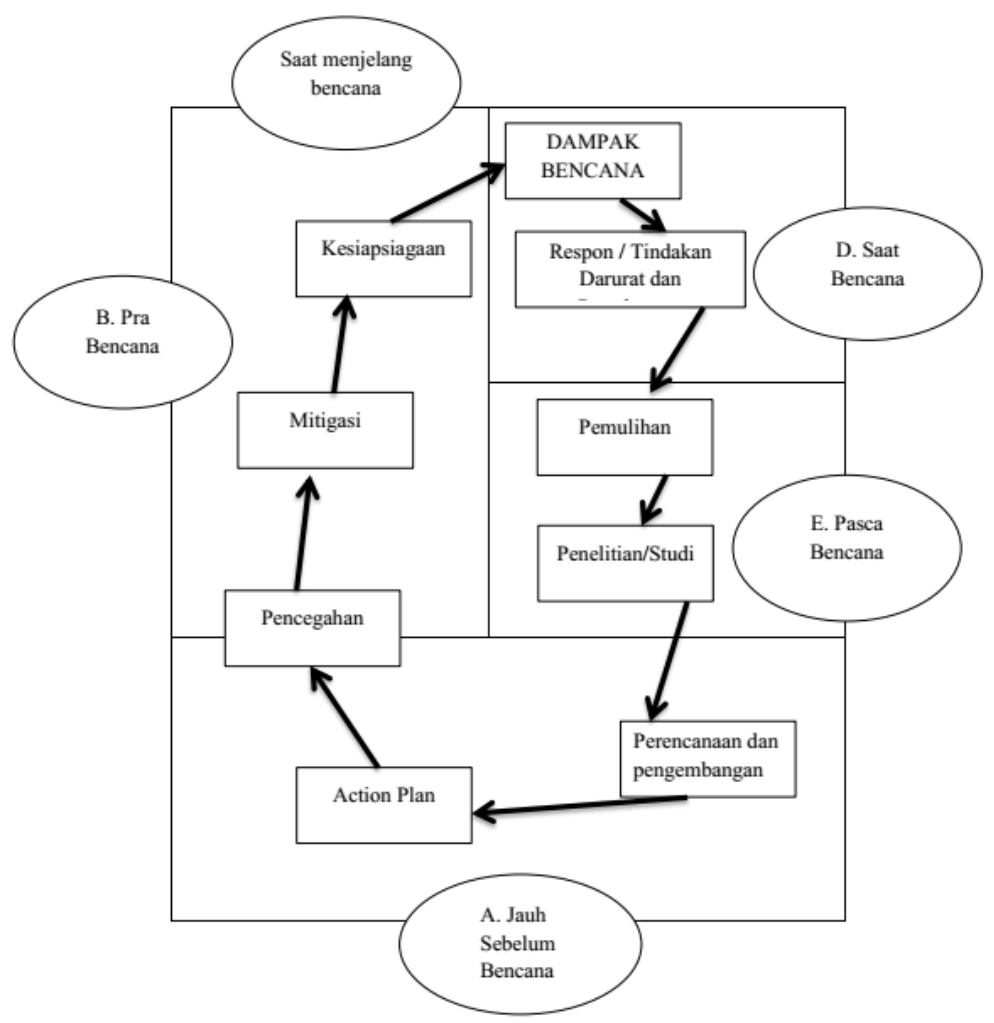

Gambar 1. Siklus Pengelolaan Bencana. Sumber : Kondoatie, Analisa Ancaman Bencana HydroMeteorologi Indonesia 2008

Walaupun pendapat para ahli tersebut berbeda namun pada intinya menyebutkan tahapan menejemen bencana dalam tiga tahap, yaitu sebelum terjadi bencana, pada waktu terjadi bencana, dan sesudah bencana terjadi. Untuk lebih jelasnya dapat dilihat pada tabel berikut:

Tabel 1. Tahapan-tahapan Manajemen Bencana

\begin{tabular}{ll}
\hline \multicolumn{1}{c}{ Peneliti } & \multicolumn{1}{c}{ Tahapan } \\
\hline Wolensky & Sebelum terjadi Bencana (Mitigation and preperadness) \\
& Tanggap darurat (Immediate pre andpost impact) \\
& Pemulihan jangka dekat (2 Tahun) \\
& Pemulihan jangka panjang (10 Tahun) \\
& Peringatan (Prevention) \\
& Perencanaan dan persiapan (Planning and prepereadness) \\
& Tanggapan (Response) \\
& Pemulihan (Recovery) \\
Helsoot dan Ruitenberg & Peringatan (Preperadness) \\
& Emergensi (Emergency) \\
& Pemulihan (Recovery) \\
\hline Sumber: Hadi Purnomo dan Rony Sugiantoro, 2010, Manajemen Bencana, Yogyakarta,
\end{tabular}

\section{METODE}

Berdasarkan tujuan yang ingin dicapai, maka metode penelitia ini dalah pendekatan positivisme dengan pendekatan kualitatif. Keyakinan dasar dari paaradigma positivsme berakar pada paham ontologi realism yang menyatakan bahwa realitas berada dalam kenyataan dan berjalan sesuai dengan hukum. Penelitian berupaya mengungkap kebenaran realitas yang ada, dan bagaimana realitas. Pedekatan positivisme ini mempunyai empat ciri, yaitu diarahkan pada fakta-fakta, diarahkan pada 
perbaikan terus menerus dari syarat-syarat hidup, berusaha kearah kepastian dan berusaha kearah kecermatan (Irawan, 2006).

Pendekatan penelitian yang digunakan dalam penelitian ini adalah pendekatan penelitian kualitatif yang dilihat dari perolehan data selama penelitian berlangsung, dimana penelitian ini mendeskripsikan cara-cara hidup, cara-cara pandang, ataupun ungkapan-ungkapan emosi dari warga masyarakat yang diteliti terkait dengan suatu gejala yang ada dalam kehiupan mereka. Maka dari itu, dalam penelitian ini menggunakan data subyektif yang merupakan prespektif dari pelaku yang diteliti (informan) tanpa adanya pengurangan atau penambahan. Hal tersebut sesuai dengan pendapat Moelong (1997) yang mengemukakan bahwa " metode kualitatif sebagai prosedur penelitian yang menghasilkan data deskriptif berupa kata tertulis atau lisan dari orang-orang dan prilaku yang dapat diamati. Penelitian kualitatif lebih menghendaki arah bimbingan penyusunan teori subtansi yang berdasarkan data.

\section{HASIL DAN PEMBAHASAN \\ Hasil}

Kota Malang adalah sebuah kota di Provinsi Jawa Timur, Indonesia. Kota ini berada di dataran tinggi yang cukup sejuk, terletak $90 \mathrm{~km}$ sebelah selatan Kota Surabaya, dan wilayahnya dikelilingi oleh Kabupaten Malang. Malang merupakan kota terbesar kedua di Jawa Timur, dan dikenal dengan julukan "kota pelajar". Terletak pada ketinggian antara $440-667 \mathrm{~m}$ dpl. Secara geografis wilayah Kota Malang berada antara

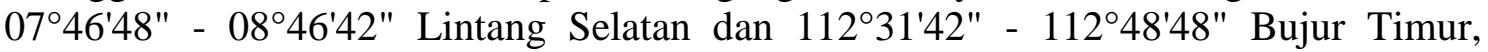
dengan dengan dikelilingi gunung-gunung diantaranya Gunung Arjuno di sebelah Utara, Gunung Tengger di sebelah Timur, Gunung Kawi di sebelah Barat, dan Gunung Kelud di sebelah Selatannya. Kota Malang memiliki luas $110.06 \mathrm{~km}^{2}$ terdiri dari 5 Kecamatan yaitu Kedungkandang, Klojen, Blimbing, Lowokwaru, dan Sukun serta 57 kelurahan.

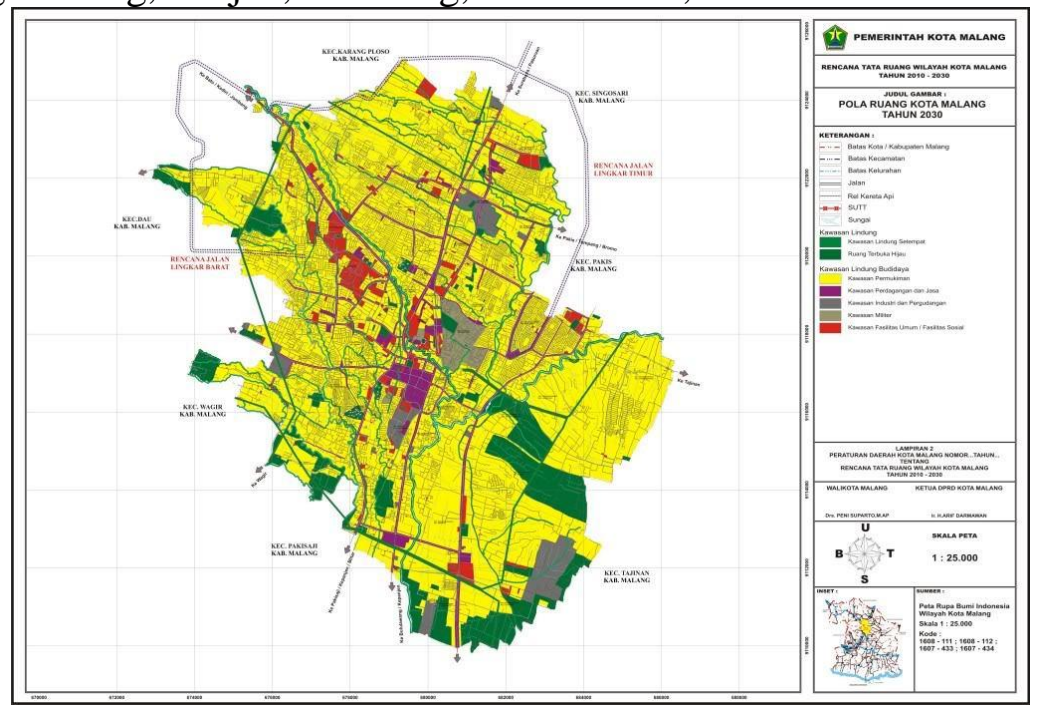

Gambar 2. Orientasi Wilayah Kota Malang

\section{Kondisi Potensi Bencana Alam}

Wilayah Rawan Bencana Kota Malang dengan topografi yang berada pada ketinggian 440-667 meter di atas permukaan laut, adalah merupakan hamparan dataran yang berada pada lokasi yang cukup tinggi. Wilayah Kota Malang yang berada pada dataran tinggi tersebut sebenarnya juga merupakan implikasi dari letaknya yang berada pada lereng-lereng dari beberapa pegunungan di sekitar Kota Malang. Diuntungkan 
dengan lokasi yang berada pada kawasan lereng pegunungan tersebut, beberapa sisi Kota Malang memiliki berbagai pemandangan yang indah serta kawasan yang sejuk dengan hawa khas pegunungan. Di lain pihak, Kota Malang juga berpotensi memiliki kawasan yang rawan bencana. Kondisi kebencanaan di Kota Malang dijelaskan pada tabel berikut:

\section{Tabel 2. Kondisi Kebencanaan di Kota Malang}

\begin{tabular}{|c|c|c|}
\hline No & Jenis Bencana & Kondisi Bencana \\
\hline 1 & Gempa Bumi & $\begin{array}{l}\text { Peristiwa gempa bumi yang terjadi di Kota Malang hanya terjadi pada } 19 \\
\text { Februari 1967, dengan korban meninggal } 14 \text { orang, korban terluka } 72 \\
\text { orang. Namun Data Dan Informasi Bencana Indonesia, Badan Nasional } \\
\text { Penanggulangan Bencana menunjukkan Kota Malang juga mempunyai } \\
\text { potensi bencana gempa bumi yang sewaktu-waktu dapat muncul kembali di } \\
\text { tahun mendatang, jadi potensi bencana ini perlu menjadi catatan. }\end{array}$ \\
\hline 2 & Banjir & $\begin{array}{l}\text { Banjir di Kota Malang disebabkan oleh tingginya curah hujan sehingga air } \\
\text { tidak mampu ditampung di saluran maupun sungai sehingga meluap. Titik- } \\
\text { titik Banjir ini tersebar di merata di Kota Malang. Salah satu lokasi adalah } \\
\text { di Jalan Soekarno Hatta. Curah hujan yang tinggi mengakibatkan genangan } \\
\text { air setinggi } 50 \mathrm{~cm} \text {. Bakesbangpol Kota Malang menyebutkan terdapat } 38 \\
\text { titik rawan banjir. Di Kecamatan Blimbing ada } 8 \text { titik rawan banjir, } \\
\text { Kecamatan Kedungkandang } 6 \text { titik rawan banjir, Kecamatan Sukun } 8 \text { titik } \\
\text { rawan banjir, Kecamatan Klojen } 5 \text { titik rawan banjir, dan Kecamatan } \\
\text { Lowokwaru } 7 \text { titik rawan banjir. Bencana banjir pada tanggal } 7 \text { November } \\
2010 \text {, mengakibatkan korban terluka } 5 \text { orang. Pada tanggal } 29 \text { Februari } \\
2008 \text { dan } 26 \text { Desember 2007, bencana banjir di Kota Malang juga terjadi, } \\
\text { namun dalam hal ini tidak ada korban jiwa (Data Dan Informasi Bencana } \\
\text { Indonesia, Badan Nasional Penanggulangan Bencana). }\end{array}$ \\
\hline 3 & Longsor & $\begin{array}{l}\text { Bakesbangpol Kota Malang menyebutkan terdapat } 23 \text { titik rawan longsor. } \\
\text { Di Kecamatan Blimbing ada } 4 \text { titik rawan longsor, Kecamatan } \\
\text { Kedungkandang } 7 \text { titik rawan longsor, Kecamatan Sukun } 7 \text { titik rawan } \\
\text { longsor, Kecamatan Klojen } 3 \text { titik rawan longsor, dan Kecamatan } \\
\text { Lowokwaru } 2 \text { titik rawan longsor. Peristiwa longsor di Kota Malang baru- } \\
\text { baru ini terjadi di tahun } 2014 \text { dan } 2011 \text { yang didapat dari Data Dan } \\
\text { Informasi Bencana Indonesia, Badan Nasional Penanggulangan Bencana: } \\
\text { 1. Waktu kejadian } 23 \text { Desember } 2015 \text {, tidak ada korban jiwa } \\
\text { 2. Waktu kejadian } 26 \text { April 2014, tidak ada korban jiwa } \\
\text { 3. Waktu kejadian } 25 \text { April 2014, tidak ada korban jiwa } \\
\text { 4. Waktu kejadian } 4 \text { Mei } 2011 \text {, tidak ada korban jiwa }\end{array}$ \\
\hline 4 & Gunung Api & $\begin{array}{l}\text { Kota Malang yang berada di tengah Kabupaten Malang ini memang tidak } \\
\text { mengalami bencana gunung api. Namun bukan berarti Kota Malang tidak } \\
\text { mempunyai potensi bencana gunung api. Data Dan Informasi Bencana } \\
\text { Indonesia, Badan Nasional Penanggulangan Bencana menunjukkan pada } \\
\text { tanggal } 1 \text { Mei } 1999 \text {, dan } 1 \text { Maret } 1998 \text {, terjadi bencana gunung api yang } \\
\text { melanda Kota Malang walaupun tidak ada korban jiwa dalam peristiwa } \\
\text { tersebut. }\end{array}$ \\
\hline 5 & Kekeringan & Tidak ada \\
\hline 6 & Tsunami & Tidak ada \\
\hline
\end{tabular}

Sumber: Kompilasi Data dari Data Dan Informasi Bencana Indonesia, Badan Nasional Penanggulangan Bencana 
Adapun wilayah Kota Malang yang terkena bencana dapat dilihat pada peta rawan bencana berikut:

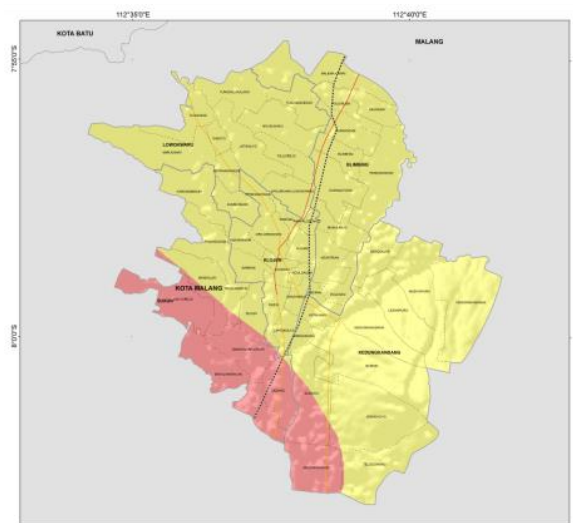

Gambar 3. Kawasan Rawan Bencana Gempa Bumi di Kota Malang

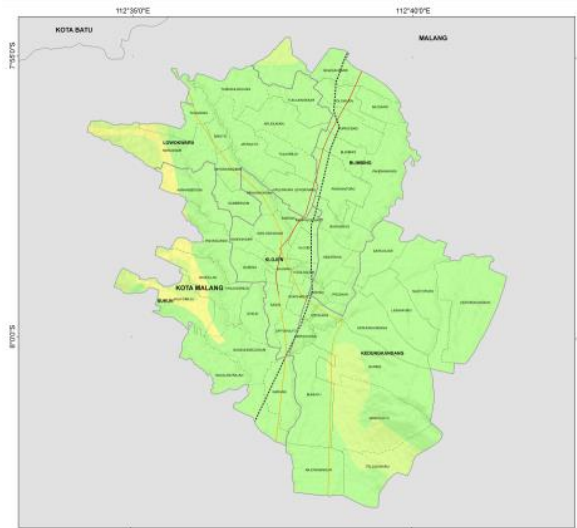

Gambar 5. Kawasan Rawan Bencana Longsor di Kota Malang

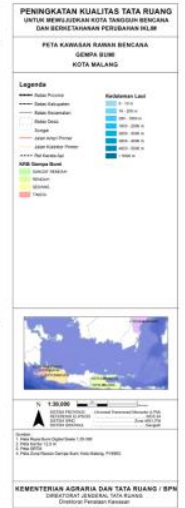

\section{Gambar 4. Kawasan Rawan Bencana Banjir di Kota Malang}

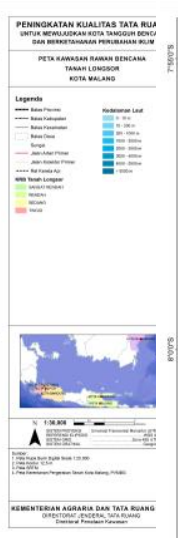

\section{Gambar 6. Kawasan Rawan Bencana Kekeringan di Kota Malang}

Berdasarkan data dari Rencana Induk D rainase Kota Malang masih terjadi beberapa genangan ketika terjadi hujan yang disebabkan oleh kapasitas saluran yang kurang, terjadinya sedimentasi, terjadinya penumpukan sampah, kondisi dimensi inlet saluran yang kurang memadai. Dalam program sanitasi juga diketahui bahwa belum semua wilayah Kota Malang memiliki fasilitas sanitasi yang memadai. Adapun penilaian tingkat ketangguhan dan ketahanan di Kota Malang diapat dilihat pada tabel di bawah ini :

Tabel 3.Penilaian Awal Ketahanan Kota Malang

\begin{tabular}{|c|c|c|c|c|}
\hline No. & Komponen & & Indikator & Keterangan \\
\hline \multirow[t]{3}{*}{1.} & $\begin{array}{l}\text { Tata Kelola } \\
\text { Pemerintahan }\end{array}$ & 1. & $\begin{array}{l}\text { Kapasitas Organisasi/ } \\
\text { penanggulangan bencana }\end{array}$ & $\begin{array}{l}\text { Kota Malang telah memiliki Badan } \\
\text { Penanggulangan Bencana Daerah } \\
\text { (BPBD) }\end{array}$ \\
\hline & & 2. & Pendanaan Daerah & $\begin{array}{l}\text { Pembiayaan/Anggaran bersumber } \\
\text { dari Dinas Perumahan dan Tata } \\
\text { Ruang (DPU) Kota Malang }\end{array}$ \\
\hline & & 3. & Partisipasi Masyarakat dan LSM & $\begin{array}{l}\text { Belum adanya forum pengurangan } \\
\text { risiko bencana di Kota Malang }\end{array}$ \\
\hline 2. & Tata ruang dan & 4. & Sistem Informasi Perencanaan & Belum adanya sistem informasi \\
\hline
\end{tabular}




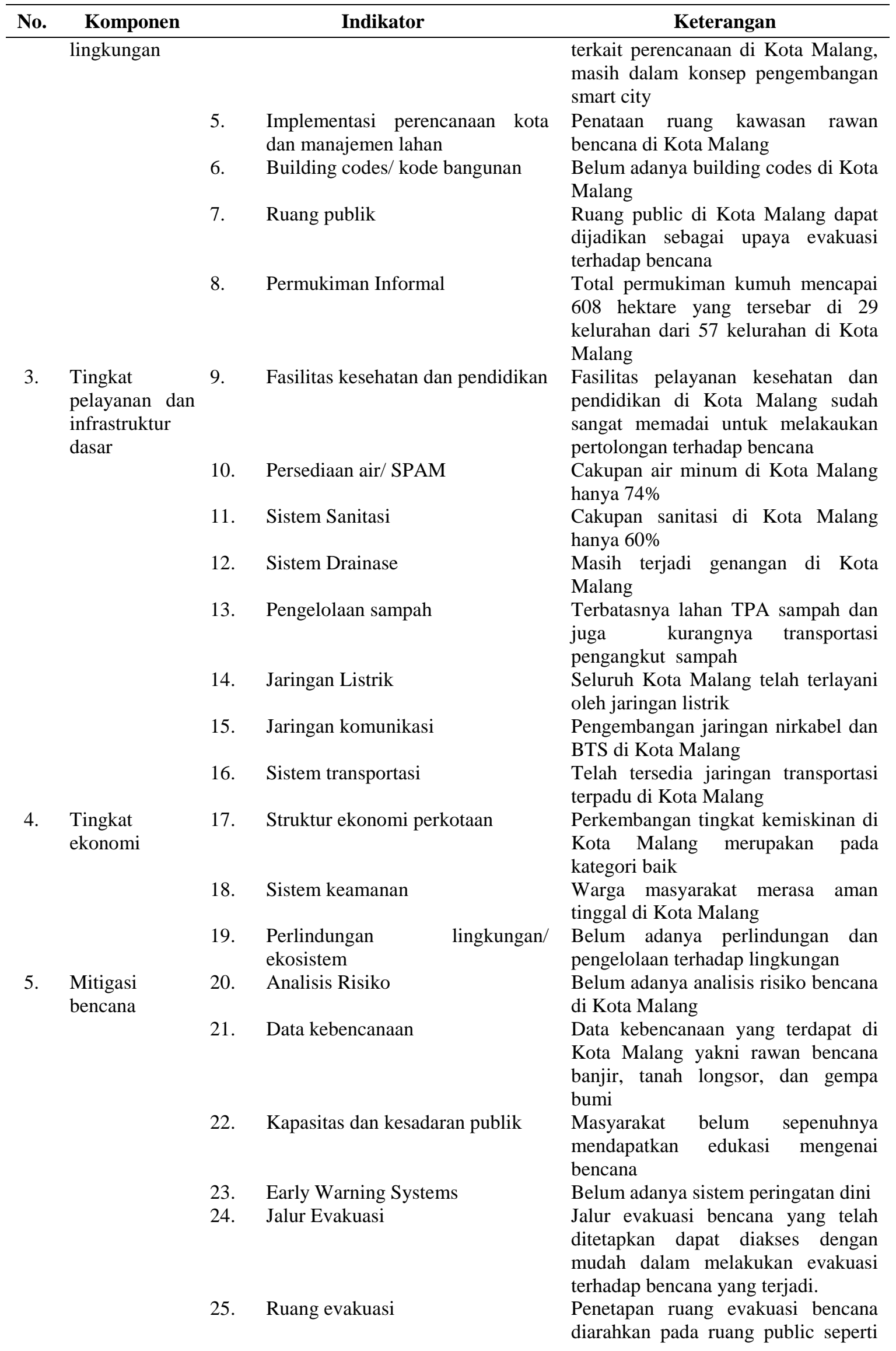




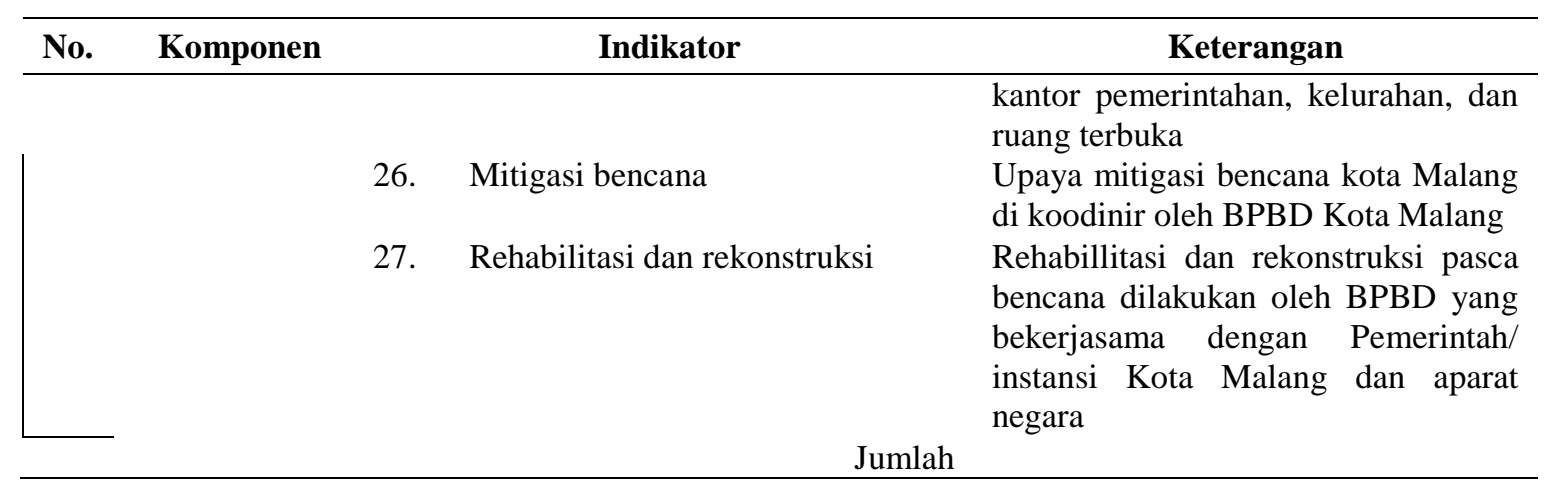

Sumber : Hasil analisis, 2017

Berdasarkan tabel di atas di ketahui bahwa tingkat ketahanan di Kota Malang masih belum maksimal dari beberapa indikator. Untuk itu perlu adanya Upaya-upaya dalam menghadapi bencana di Kota Malang dikoordinasikan oleh BPBD Kota Malang terkait upaya mitigasi bencana.

\section{Pembahasan}

Mitigasi yang akan dilakukan di Kota Malang meliputi strutural dan nonstruktural. Seperti halnya yang diutarakan oleh Carter bahwa kegiatan mitigasi bencana dibagi menjadi dua yaitu struktural dan non-struktural (Carter, 1991). Adapun penjelasan dari mitigasi yang dilakukan di Kota Malang adalah sebagai berikut:

a) Mitigasi Struktural

Mitigasi strukural merupakan upaya untuk meminimalkan bencana yang dilakukan melalui pembangunan berbagai prasarana fisik dan menggunakan pendekatan teknologi. Upaya pemerintah Kota Malang dalam meningkatkan kesiapsiagaan dalam menghadapi ancaman bencana dari segi fisik yaitu

$\checkmark$ Perbaikan saluran drainase perkotaan

$\checkmark$ Memperbanyak RTH maupun RTNH

$\checkmark$ Gencar dalam program penghijauan dengan membangun taman kota dimana sebagai tempat wisata juga berguna untuk RTH perkotaan

$\checkmark$ Normalisasi sungai

$\checkmark$ Melakukan penghijauan di bantaran sungai Brantas dan sungai kecil lainnya.

$\checkmark$ Pemotongan pohon besar dijalan

b) Mitigasi Non-Struktural

Mitigasi non -struktural adalah upaya mengurangi dampak bencana selain dari upaya tersebut diatas. Bisa dalam lingkup upaya pembuatan kebijakan seperti pembuatan suatu peraturan. Undang-Undang Penanggulangan Bencana (UU PB) adalah upaya non-struktural di bidang kebijakan dari mitigasi ini. Adapun upaya pemerintah Kota Malang dalam meningkatkan kesiapsiagaan dari segi non struktural yaitu:

$\checkmark$ Peraturan Daerah Kota Malang Nomor 1 Tahun 2017 Tentang Penyelenggaraan Penanggulangan Bencana

$\checkmark$ Rencana Strategis (RENSTRA) BPBD Kota Malang Tahun 2015 - 2018

$\checkmark$ Pemerintah Kota Malang melibatkan seluruh lapisan masyarakat, terutama mereka yang paling rentan secara fisik, ekonomi, lingkungan, sosial dan keyakinan, termasuk perhatian khusus pada upaya pengarusutamaan gender.

$\checkmark$ Membangun sinergi program dengan seluruh pelaku (kementerian, lembaga negara, organisasi sosial, lembaga usaha, dan perguruan tinggi) untuk memberdayakan masyarakat Kelurahan

$\checkmark$ Melakukan simulasi Peningkatan pengetahuan dan kesadaran masyarakat akan potensi ancaman di Kelurahan dan kerentanan yang dimiliki 
$\checkmark$ Peningkatan kapasitas masyarakat untuk mengurangi dan beradaptasi dengan risiko bencana dengan melakukan simulasi maupun pengarahan

$\checkmark$ Penerapan analisis keseluruhan rangkaian manajemen risiko mulai dari identifikasi risiko, pengkajian risiko, penilaian risiko, pencegahan, mitigasi, pengurangan risiko, dan transfer risiko

$\checkmark$ Pengarusutamaan pengurangan risiko bencana ke dalam perencanaan program dan kegiatan lembaga/institusi sosial Kelurahan, sehingga PRB menjiwai seluruh kegiatan di tingkat masyarakat

Menurut arah kebijakan penanggulangan bencana dalam RPJMN 2015 - 2019 untuk mengurangi risiko bencana dan meningkatkan ketangguhan pemerintah, pemerintah daerah dan masyarakat dalam menghadapi bencana. Strateginya adalah:

1. Internalisasi pengurangan risiko bencana dalam kerangka pembangunan berkelanjutan di pusat dan daerah, melalui:

a. Pengarusutamaan pengurangan risiko bencana dalam perencanaan pembangunan nasional dan daerah;

b. Pengenalan, pengkajian dan pemantauan risiko bencana melalui penyusunan kajian dan peta risiko skala 1:50.000 pada kabupaten dan skala 1:25.000 untuk kota, yang difokuskan pada kabupaten/kota risiko tinggi terhadap bencana;

c. Pemanfaatan kajian dan peta risiko bagi penyusunan Rencana Penanggulangan Bencana (RPB) Kabupaten/Kota dan Rencana Aksi Daerah Pengurangan Risiko Bencana (RAD PRB), yang menjadi referensi untuk penyusunan RPJMD Kabupaten/Kota;

d. Integrasi kajian dan peta risiko bencana dalam penyusunan dan review RTRW Provinsi/Kabupaten/Kota;

e. Harmonisasi kebijakan dan regulasi penanggulangan bencana di pusat dan daerah;

f. Penyusunan rencana kontijensi pada kabupaten/kota yang berisiko tinggi sebagai panduan kesiapsiagaan dan operasi tanggap darurat dalam menghadapi bencana.

2. Penurunan tingkat kerentanan terhadap bencana, melalui:

a. Mendorong dan menumbuhkan budaya sadar bencana serta meningkatkan pengetahuan masyarakat tentang kebencanaan;

b. Peningkatan sosialisasi dan diseminasi pengurangan risiko bencana kepada masyarakat baik melalui media cetak, radio dan televisi;

c. Penyediaan dan penyebarluasan informasi kebencanaan kepada masyarakat;

d. Meningkatkan kerjasama internasional, mitra pembangunan, Organisasi Masyarakat Sipil (OMS) dan dunia usaha dalam penyelenggaraan penanggulangan bencana;

e. Peningkatan kualitas hidup masyarakat di daerah pasca bencana, melalui percepatan penyelesaian rehabilitasi dan rekonstruksi wilayah pasca bencana alam;

f. Pemeliharaan dan penataan lingkungan di daerah rawan bencana alam; dan

g. Membangun dan menumbuhkan kearifan lokal dalam membangun dan mitigasi bencana.

3. Peningkatan kapasitas pemerintah, pemerintah daerah dan masyarakat dalam penanggulangan bencana, melalui:

a. Penguatan kapasitas kelembagaan dan aparatur penanggulangan bencana di pusat dan daerah; 
b. Penguatan tata kelola, transparansi dan akuntabilitas penyelenggaraan penanggulangan bencana;

c. Penyediaan sistem peringatan dini bencana kawasan risiko tinggi serta memastikan berfungsinya sistem peringatan dini dengan baik;

d. Pengembangan dan pemanfaatan IPTEK dan pendidikan untuk pencegahan dan kesiapsiagaan menghadapi bencana;

e. Melaksanakan simulasi dan gladi kesiapsiagaan menghadapi bencana secara berkala dan berkesinambungan di kawasan rawan bencana;

f. Penyediaan infrastruktur mitigasi dan kesiapsiagaan (shelter/tempat evakuasi sementara, jalur evakuasi dan rambu-rambu evakuasi) menghadapi bencana, yang difokuskan pada kawasan rawan dan risiko tinggi bencana;

g. Pembangunan dan pemberian perlindungan bagi prasarana vital yang diperlukan untuk memastikan keberlangsungan pelayanan publik, kegiatan ekonomi masyarakat, keamanan dan ketertiban pada situasi darurat dan paska bencana;

h. Pengembangan Desa Tangguh Bencana di kawasan risiko tinggi bencana untuk mendukung Gerakan Desa Hebat;

i. Peningkatan kapasitas manajemen dan pendistribusian logistik kebencanaan, melalui pembangunan pusat - pusat logistik kebencanaan di masing-masing wilayah pulau, yang dapat menjangkau wilayah pasca bencana yang terpencil

Berdasarkan hasil formulasi strategi yang telah dikembangkan dan ditetapkan, kebijakan yang diambil untuk melaksanakan Program dan Kegiatan BPBD Kota Malang untuk jangka waktu tahun 2015 - 2018 adalah sebagai berikut:

a. Melaksanakan kajian risiko bencana dan pemetaan detail kerawanan bencana pada skala $1: 5.000$ pada tingkat kecamatan;

b. Melaksanakan sosialisasi, diseminasi, penyebaran brosur / leaflet, pemasangan banner di lokasi strategis, pembuatan situs internet, dan penyiaran di media massa;

c. Membentuk relawan 1` - relawan penanggulangan bencana di tingkat kelurahan sebagai garda terdepan pencegahan \& penanggulangan bencana di lokasi - lokasi rawan bencana;

d. Melaksanakan pelatihan/bimbingan teknis secara kontinyu terhadap aparatur/relawan penanggulangan bencana;

e. Menyediakan sarana prasarana dan logistic penanggulangan bencana yang memadai baik melalui dana APBD maupun APBN;

f. Menyusun dasar hukum tertulis untuk menjadi acuan dalam penanggulangan bencana dan berkomunikasi secara intensif, harmonis, dan efektif dengan stakeholder penanggulangan bencana;

g. Menyusun rencana kerja dan anggaran program rehabilitasi dan rekonstruksi melalui analisis teknis yang memadai dengan basis partisipasi dan pemberdayaan masyarakat;

h. Menyusun dasar hukum tertulis dan menjalin komunikasi yang harmonis dan efektif dengan stakeholder lainnya dalam rangka dasar pelaksanaan rehabilitasi dan rekonstruksi bagi korban bencana;

i. Memantau secara kontinyu kondisi korban bencana dan melaksanakan survey kepuasan publik secara berkala. 


\section{Menafsirkan Temuan Penelitian}

BPBD sebagai penanggung jawab dan leading sektor penanggulangan berdasarkan Perda No. 4 Tahun 2011 telah melakukan beberapa inisiatif strategis untuk menjamin terwujudnya sistem penanggulangan bencana yang handal. Beberapa inisiatif startegis tersebut yaitu:

1. Penyusunan regulasi yang kuat khususnya terkait dengan penanggulangan bencana dan pengurangan resiko bencana.

2. Peningkatan komitmen stakeholder khususnya masyarakat, kebijakan ini merupakan langkah stategis untuk merangkul, memberdayakan serta meningkatkan peran serta seluruh pelaku utama dalam penanggulangan bencana mulai dari pemerintah, masyarakat (civil society) serta dunia usaha.

Tabel 4. Keterkaitan SKPD dalam Penanganan Bencana

\begin{tabular}{cll}
\hline NO & \multicolumn{1}{c}{ Jenis Bencana } & \multicolumn{1}{c}{ SKPD Terkait } \\
\hline 1 & Tanah Longsor & BLH, Dinas Kehutanan, DInas Pertanian, DInas Bina \\
& & Marga \\
2 & Banjir & Dinas Pengairan, Dinas Cipta Karya dan Tata Ruang \\
3 & Kekeringan & BLH, Dinas Kehutanan, Dinas Pengairan \\
4 & Kebakaran & Dinas Bina Marga, BLH \\
\hline
\end{tabular}

Hasil Analisis, 2017

Secara rinci bentuk kerjasama lintas sektor dengan SKPD dan lembaga pemerintah lainnya yang terkait dijelaskan sebagai berikut:

1. kerjasama dalam penyusunan rencana kontijensi yang melibatkan beberapa SKPD terkait

2. BMKG dan PVMBG bandung secara rutin dan berkala mengirimkan bulletin dan berita terkait pelatihan mitigasi bencana

3. Institusi lain yang terlibat adalah: Palang Merah Indonesia (PMI), Lembaga Swadaya Masyarakat (LSM), Taruna Siaga Bencana (TAGANA), SAR Trenggana, Pramuka dan BUMN lainnya

\section{KESIMPULAN}

1. Tingkat ketahanan di Kota Malang masih belum maksimal dari beberapa indikator. Untuk itu perlu adanya Upaya-upaya dalam menghadapi bencana di Kota Malang dikoordinasikan oleh BPBD Kota Malang terkait upaya mitigasi bencana.

2. Peran pemerintah Kota Malang dalam meningkatkan kesiapsiagaan masyarakat dalam menghadapi bencana yaitu dengan mitigasi struktural dan mitigasi non struktural.

\section{DAFTAR PUSTAKA}

Carter, Nick W. (1991). Disaster Management: A Disaster Manager's Handbook, ADB Manila

Purnomo, Hadi dan Rony Sugiantoro. (2010). Manajemen Bencana. Yogyakarta: Media Pressindo.

Moleong, Lexy. (1997). Metode Penelitian Kualilatatif. Bandung: PT. Remaja Rosda Karya. P.

Peraturan Daerah Kota Malang Nomor 1 Tahun 2017 Tentang Penyelenggaraan Penanggulangan Bencana

Perda No. 4 Tahun 2011 tentang Rencana Tata Ruang Wilayah Kota Malang Tahun $2010-2030$ 
Irawan, Prasetya. (2006). Penelitian Kualitatif Dan Kuantitatif Untuk Ilmu-Ilmu Sosial, Jakarta.

Rencana Strategis (RENSTRA) BPBD Kota Malang Tahun 2015 - 2018 Undang Undang No. 26 tahun 2007 tentang Penataan Ruang.

Noor, Djauhari. (2014). Mitigasi Bencana Geologi. Yogyakarta: Deepublish.

Simanjuntak, Entatarina, dkk. (2016). Strategi dan Rencana Pengembangan Infrastruktur Pekerjaan Umum dan Perumahan Rakyat (PUPR) di Pulau JawaBali tahun 2015-2025. Jakarta: Pusat Perencanaan Infrastruktur Pekerjaan Umum dan Perumahan Rakyat, Badan Pengembangan Infrastruktur Wilayah, Kementerian Pekerjaan Umum dan Perumahan Rakyat.

Khan, Himayatillah. 2008. Disaster management Cycle A Theoritical Approach. (Pakistan, Institute information technology Abbotabbad.

TIM LIPI. (2006). Kajian kesiapsiagaan masyarakat dalam mengantisipasi bencana gempa dan tsunami. Bandung: LIPI 